\title{
How Do HRM Practices Relate To Innovation Performance In Information Technology Firms
}

\author{
Eva Petiz LOUSÃ, Ana Cláudia RODRIGUES and Eulália Matos PINTO
}

CEOS.PP/ISCAP/P.PORTO, Rua Jaime Lopes Amorim s, Matosinhos, Portugal

Correspondence should be addressed to: Ana Cláudia RODRIGUES; anarodrigues@iscap.ipp.pt

Received date:1 October 2019 ; Accepted date: 1 February 2020 ; Published date: 8 June 2020

Academic Editor: Dora Martins

Copyright (C) 2020. Eva Petiz LOUSÃ, Ana Cláudia RODRIGUES and Eulália Matos PINTO.Distributed under Creative Commons Attribution 4.0 International CC-BY 4.0

\begin{abstract}
This paper investigates the relation between Human Resources Management (HRM) and innovation/performance in four firms operating in the Information Technology sector. A qualitative multiple case study methodology was used, and data collection included a documentary information analysis, and semi-structured interviews were held with HRM and innovation-related functions. The main results revealed that HRM practices are related to the best innovation and performance outputs. Moreover, some sector-specific HRM practicesInnovation/performance relations were found, with which prepositions are proposed. There is a high level of recruitment and selection, as well as compensation (salary, benefits and nonfinancial pay) practices due to the increasing need for these professionals in the labor market. Considering the generalization of compensation and benefits practices in the IT sector, it seems that the production of patents/utility models in organisations is more related to the investment in training and development, then to compensations and benefits practices. Few HRM practices that focus on promoting autonomy and self-management have a positive effect on innovation and can be at least as effective as a wider number of corporate HRM practices. This study contributes to the HRM relation to innovation performance literature, by its qualitative and longitudinal nature, the use of objective innovation and performance measures, and the prepositions specific to the IT sector that are suggested for future validation.
\end{abstract}

Keywords: Human Resources Management Practices, Information Technology Sector, Innovation, Performance. 


\section{Introduction}

Increasing globalization and business dynamics encourage companies to become innovative in responding to threats and opportunities that arise in this competitive market (Donate, Penã and Pablo, 2016). Human resources management (HRM) researchers and practitioners have focused on the relationship of their practices with organizational performance (e.g. Boselie, Paauwe and Jansen, 2001) and with innovation (Chen and Huang, 2009; DiazFernandez, Bornay-Barrachina and LopesCabrales, 2017; Jiménez-Jiménez and SanzValle, 2008; Shipton, Fay, West, Patterson and Birdi, 2005, Hong, Zhao and Snell, 2018 , and Seeck and Diehl, 2016), as well as the performance-innovation binomial (Gomes, Hurmelina and Olander, 2018). We are currently witnessing an outpouring and growth of technology companies globally and locally, and the HRM practices link to innovation and performance in technological firms is not explicitly studied. Challenges presented by this sector, namely its volatility,which is subjected to rapid technological changes (McAfee and Brynjolfsson, 2008), pressured to continually adapt to market (Pan, Huang and Gopal, 2016), and technological changes (Becker and Gerhart, 1996), explain the need for constant innovation if they want to survive and much more if they want to improve organizational performance.

People are at the center of innovation and the way people are managed, through HRM practices, affects innovation (Galbraith 1984, and Jiménez-Jiménez and Sanz-Valle, 2008). However, despite a growing increase in publications in this domain, this field of research is fragmented and presents some gaps that this paper aims to fill with this study, namely regarding the measurement of HRM practices and innovation, as well as the research design since there are few qualitative, longitudinal and comparative studies (Seeck and Diehl, 2016). These gaps present an opportunity to investigate further: How do HRM practices relate to innovation/performance in information technology (IT) firms?. Specifically, the aim is to: (1) identify and characterize HRM practices adopted on the studied firms; (2) identify and characterize innovation/performance; and (3) analyze the relationship between HRM practices, performance and innovation in IT firms.

The contribution to this exploratory study is to expand the existing literature in the HRM-innovation and performance link in the specific context of the Information Technology (IT) sector. The next sectionperforms a review of the literature on the concepts of HRM practices, innovation, performance and the link between them, followed by the presentation of the methodology and the results of the multiple case study performed. Finally, this study discusses, concludes and highlights some prepositions that can be used for future verification.

\section{Literature Review}

There is an extensive literature that links HRM practices to organizational performance; some meta-analysis which examined that relation are: (e.g. Combs, Liu, Hall and Ketchen, 2006; Posthuma, Campion, Masimova and Campion, 2013; Rauch and Hatak, 2016 and Subramony, 2009). Rauch and Hatak (2016) studied 56 independent samples of small and medium sized enterprises. They organized the studies in the dimensional human resources (HR) enhancing practices model proposed by Subramony (2009), which in turn was inspired by the AMO (ability, motivation, opportunity) framework: skill-enhancing, motivation-enhancing and empowermentenhancing practices. Posthuma et al. (2013) aiming to create a high-performance work practice category guide, analyzed data collected in 193 journal articles and published between 1992 and 2011, and found 61 individual practices, organizing them into nine categories: (1) compensation and benefits, (2) job design, (3) training and development, (4) recruitment and selection, employee/work environment relationships, (6) communication, (7) performance 
management and evaluation, (8) promotions/progression and (9) turnover, retention and exit management.

Studies that link HRM to innovation show that the capacity of an organization to innovate relies on the skills and motivation of its employees (Jiménez-Jiménez and Sanz-Valle, 2008). However, there are several approaches to HRM practices measurement when relating them to innovation. Usually, the scholars, based on literature, decide which are the best HRM practices to search for and measure, studying them in bundles, different in their content (e.g. Shipton et al. 2005, and Verburg, Den Hartog and Koopman, 2007), and which Seeck and Diehl (2016) point out that they have not been consistent (see also Posthuma et al. 2013 for a deeper discussion). This study identifies the HRM practices bundles used by each firm, which allows understanding the choices of each firm, in a deeper way into the analysis. To do that, Posthuma et al. (2013) work is used as the theoretical model for HRM practices in the present work due to the recency of the study when compared to several others, also it is the model based on the widest range (and number) of studies, and this model covers a large number of individual HRM practices which is adequate, given the exploratory nature of the present study.

Furthermore, the same inconsistency in operationalization and measurement is evident when the studies in the field of innovation are analyzed (Seeck and Diehl, 2016). The review of the innovation literature shows that this is a very broad and complex domain (e.g. Damanpour and Schneider, 2006; Lousã and Gomes, 2017 and Wolfe, 1994) and highlights the existence of different phases, types and operationalizations of innovation. The present study intends to contribute to a better operationalization of innovation measurement adopting a more comprehensive and integrated model of the innovation dynamics (see Lousã and Gomes, 2017 for a deeper discussion). As Adams, Bessant and Phelps (2006) mentioned, the fragmentation of innovation measurement is due to their focus either on innovation inputs or outputs measurements.

According to OECD (2005), innovation is about the implementation of a new or significantly improved product (good or service) or process, a new marketing or a new organizational method in business practices, workplace organization or external relations. The product innovation concerns the introduction of a new good or service or a significant improvement concerning its expected characteristics or uses, which includes significant improvements in technical specifications, components and materials, embedded software, ease of use or other functional characteristics. Process innovation refers to the implementation of a new or considerable improvement in the production or the delivery method, covering changes in techniques, equipment and software. Marketing innovation refers to the introduction of a new marketing method, which involves changes in product design or packaging, product placement, product promotion or pricing. Furthermore, organizational innovation includes the implementation of a new organizational method in the business practices, in the workplace, or in its external relations. Lousã and Gomes (2017), based on previous literature (e.g. Amabile, Conti, Coon, Lazenby,\& Herron, 1996, and Damanpour and Schneider, 2006), expanded this notion of innovation considering that this process involves the creation of new ideas or significant improvements and the implementation of those ideas in products or services, business processes, work organization and marketing.

Lousã (2013) developed and built an innovation model, combining a series of objective and perceptual indicators in order to understand how innovation occurs within and between different industries or companies, namely the information technology sector. This model has three dimensions: Resources, Processes and Results. Resources refer to the characterization of human resources, available resources and expenditure on Research and Development. Processes 
encompass partnerships and networks of cooperation and protection and application of knowledge. Finally, Results consist of the turnover of the last three years; the evolution of product/service sales or significant improvements in the last three years; and the percentage of ideas generated and transformed into innovative projects and the image of the company. As Lousã and Gomes (2017) pointed out, these indicators seem useful not only to compare innovation activities between companies but also to understand their innovation dynamics within each company. Interestingly, the results dimension indicators in the innovation model are the same as organizational performance indicators when studying the HRMperformance link (turnover, commitment, employee growth, revenue and sales) (e.g. Boselie et al. 2001 and Huselid, 1995). So this study will refer to the set of these indicators as innovation performance.

At last, another gap, which the present investigation seeks to fill, refers to the methodologies used in the investigations that have linked HRM practices to innovation, as Seeck and Diehl (2016) referred that the qualitative studies in this area are scarce, and the realization of qualitative, longitudinal and comparative studies are recommended to a better understanding of this dynamic.

\section{Methodology}

This study is exploratory and adopted a qualitative multiple case study methodology. It developed a data collection protocol to perform the data collection process with the best reliability (Yin, 1994).

The data collection process included a semistructured analysis and the analysis of documentation by each firm such as published articles, reports, websites and the database that contains comprehensive information on companies in Spain and Portugal - SABI (Iberian Balance sheet Analysis System).

\section{Participants}

The four firms studied in this multiple case study research were selected based on the sector information technology), the same city (geographical area) and the convenience of the research team.

A total of seven participants were interviewed (4 performing HRM functions and 3 performing innovation-related functions) from four IT firms in Porto, Portugal. The participants worked in the company from 1 to 17 years and the majority have university degrees qualifications. Companies were founded from 5 to 18 years ago (cf. Table 1). The firm's activities are displayed in Table 1.

Table 1 : Characterization of the case studies

\begin{tabular}{|c|c|c|c|c|}
\hline & Firm A & Firm B & Firm C & Firm D \\
\hline Founded in & 2001 & 2014 & 2008 & 2009 \\
\hline $\begin{array}{c}\text { Companies' } \\
\text { legal forms }\end{array}$ & $\begin{array}{c}\text { Public limited } \\
\text { company }\end{array}$ & $\begin{array}{c}\text { Public } \\
\text { limited } \\
\text { company }\end{array}$ & $\begin{array}{c}\text { Single-member } \\
\text { limited company }\end{array}$ & $\begin{array}{c}\text { Public limited } \\
\text { company }\end{array}$ \\
\hline $\begin{array}{c}\text { Number of } \\
\text { business } \\
\text { partners }\end{array}$ & 3 & 5 & 1 & 1 \\
\hline $\begin{array}{l}\text { Number of } \\
\text { employees }\end{array}$ & 18 & 133 & 58 & 20 \\
\hline
\end{tabular}




\begin{tabular}{|c|c|c|c|c|}
\hline $\begin{array}{l}\text { Business } \\
\text { field }\end{array}$ & Web applications & $\begin{array}{l}\text { Web and } \\
\text { mobile } \\
\text { applicatio } \\
\text { ns }\end{array}$ & $\begin{array}{l}\text { Multichannel } \\
\text { platform of digital } \\
\text { marketing }\end{array}$ & $\begin{array}{l}\text { Higher education } \\
\text { management } \\
\text { software and } \\
\text { HRM software for } \\
\text { public services }\end{array}$ \\
\hline $\begin{array}{c}\text { Academic } \\
\text { qualification } \\
\text { s and HRM } \\
\text { Responsibili } \\
\text { ty }\end{array}$ & $\begin{array}{l}\text { Engineering/Found } \\
\text { ers }(n=3)\end{array}$ & $\begin{array}{l}\text { No HRM } \\
\text { role } \\
\text { assigned } \\
\text { formally } \\
\text { as a } \\
\text { strategic } \\
\text { option } \\
(\mathrm{n}=0)\end{array}$ & $\begin{array}{l}\text { Psychologist/Hum } \\
\text { an Resource } \\
\text { Director }(n=1)\end{array}$ & $\begin{array}{l}\text { Engineering/Shar } \\
\text { ed by the General } \\
\text { manager/ Chief } \\
\text { Architect/ Chief } \\
\text { Operating Officer } \\
(n=3)\end{array}$ \\
\hline $\begin{array}{c}\text { Academic } \\
\text { qualification } \\
\text { s of } \\
\text { Innovation } \\
\text { Responsable }\end{array}$ & Engineering & $\begin{array}{c}\text { Engineerin } \\
\mathrm{g}\end{array}$ & Engineering & Engineering \\
\hline
\end{tabular}

\section{Data Collection Instrument's}

The dominant strategy for data collection was the semi-structured interview. In order to ensure the validity and accuracy of the data to be collected, the interview guide was reviewed by two innovation and HR experts and was pre-tested.

The interview guide had four parts: characterization and evolution of the organization, HRM practices, performance and innovation. Specific questions were elaborated for the participant who performs the HR roles, such as "What are the HRM practices adopted in the organization and how do you characterize them?"; and other questions for the participant who performs the innovation-related roles, such as "How does the innovation process unfold?"; "Which HRM practices contribute most to innovation?, and "Is the innovation process carried out intentionally?" Information was also requested regarding the identification of the organization, the date of the interview, and the characterization of the participant, his educational background, number of his employment years and his role in the organization.

\section{Procedures and Data Analyses}

The interviews took place at the premises of the participating companies. The interviews have an average duration of 60 minutes. Data collection started in September 2018 and ended in April 2019.

This studyused the content analysis of the interviews conducted and the information on the website and the professional and social networks of each organization, as well as the information contained in the documents provided by companies and data reports collected in the SABI database (Bardin, 2018).

The validity of the analysis and coding process was ensured by the consultation of two independent researchers who discussed and validated the categories throughout the data analysis process.

\section{Results}

To analyze the case studies, the following were considered: the nine HRM practices categories of Posthuma et al. (2013) together with their 61 individual HRM practices and the three innovation dimensions proposed by Lousã (2013) and Lousã and Gomes (2017), that include the performance indicators as productivity (ratio of turnover per employee) (Huselid, 1995), profit per employee (necessary to have a comparative base-line of analyzes) and employment growth (number of employees at a fiscal year) (Rauch, Frese and Utsch, 2005). 


\section{Human Resource Management Practices}

The HRM practices of the four case studies were analyzed according to the categories proposed by Posthuma et al. (2013) and the relation to innovation mentioned in the interviews. Results are summarised in Table 2 and detailed in Appendix A.

The most commonly used categories of HRM practices are Recruitment and Selection ( $n=16)$ (firms $C, n=6$ and $C, n=4)$ ), Compensation and Benefits ( $\mathrm{n}=14$ ) (firms A, $\mathrm{n}=5$ and $\mathrm{D}, \mathrm{n}=4)$, Job and Work Design $(\mathrm{n}=10) \quad($ firm $\mathrm{B}, \mathrm{n}=5)$, Training and Development $(\mathrm{n}=10)$ (firms $\mathrm{C}, \mathrm{n}=4 \mathrm{e}$ and $\mathrm{A}$, $n=3$ ), and Performance Management and Appraisal ( $n=9$ ) (firms $A, n=4$ and $D, n=3$ ).
Firm $\mathrm{C}$ is the one that uses the widest range and number of HRM practices $(n=24)$, followed, from some distance, by firm $A$ $(n=19)$. Both firms; B and D, use less HRM practices.

Although all firms acknowledge the importance of their employees and of HRM practices to attract, develop and retain them, maybe due to the recognition of qualified labor in the market in this specific sector, they all address the "people issue" differently. The interviews allowed to understand the philosophy underneath the practices.

Table 2 : HRM categories in the case studies (Postuma et al., 2013)

\begin{tabular}{|c|c|c|c|c|c|}
\hline Categories of HRM practices & Firm A & Firm B & Firm C & Firm D & Total \\
\hline Compensation and Benefits & 5 & 2 & 3 & 4 & 14 \\
\hline Job and Work Design & 1 & 5 & 2 & 2 & 10 \\
\hline Training and development & 3 & 1 & 4 & 2 & 10 \\
\hline Recruitment and selection & 3 & 4 & 6 & 3 & 16 \\
\hline $\begin{array}{l}\text { Employee Relationship / } \\
\text { Work Environment }\end{array}$ & 0 & 2 & 3 & 0 & 5 \\
\hline Communication & 2 & 2 & 2 & 1 & 7 \\
\hline $\begin{array}{l}\text { Performance Management } \\
\text { and Appraisal }\end{array}$ & 4 & 0 & 2 & 3 & 9 \\
\hline Promotions / Progression & 0 & 0 & 2 & 0 & 2 \\
\hline $\begin{array}{l}\text { Turnover, Retention and Exit } \\
\text { Management }\end{array}$ & 1 & 0 & 0 & 0 & 1 \\
\hline $\begin{array}{l}\text { Total number of HRM } \\
\text { practices }\end{array}$ & 19 & 16 & 24 & 15 & \\
\hline HRM relation to Innovation & $\begin{array}{c}\text { All } \\
\text { practices }\end{array}$ & $\begin{array}{c}\text { All } \\
\text { practices, } \\
\text { accent on } \\
\text { employees } \\
\text { self- } \\
\text { manageme } \\
\text { nt }\end{array}$ & $\begin{array}{c}\text { All } \\
\text { practices; } \\
\text { emphasizes } \\
\text { on } \\
\text { Recruitmen } \\
\text { t and } \\
\text { Selection }\end{array}$ & $\begin{array}{l}\text { Integrated } \\
\text { on a daily } \\
\text { informal } \\
\text { environme } \\
\text { nt, but not } \\
\text { intentionall } \\
\text { y } \\
\text { implement } \\
\text { ed }\end{array}$ & \\
\hline
\end{tabular}

Generally, all firms use HRM practices intended to enhance innovation and performance, however, firm D informally does that, as the daily environment unfolds.
Firm C emphasizes recruitment and selection as a means to increase its pool of talent and enhance innovation and performance, which is congruent with the 
high number of practices. Firm B, in its management philosophy, intentionally does not have any structured process, including the people related ones. This management posture explains a higher number of job and work design since the emphasis is on selfmanaged teams, autonomy, decentralized decision making, which allows to understand that there may be a lot of HRM practices going on, but in an informal and not structured way, aiming at fulfilling the employees' needs. Alternatively, the HRM practices that are going on informally are occasional and on-demand according to employees need, that is to say organically, and therefore not reported as 'HRM practices' because it is not felt in that way. There is a difference regarding firm D, which, being informal in its environment, does not have the intention of that informality. It is also interesting to note that firm $B$ is the one that reports a fewer number of practices related to compensation and benefits, which may be due to the managing philosophy that emphasizes autonomous job and work design.

\section{Innovation and Performance}

To characterize innovation in the four case studies, this study refers to the period from 2015 to 2017 and uses the innovation model dimensions of Lousã (2013): Resources, Processes and Results of Innovation. The Results of Innovation are the same as Organizational Performance indicators (Table 3). This study performed a more detailed analysis of firms B and C, and a less detailed analysis of firms A and D, as it was not possible to access most of the data.

Table 3 : Innovation dimensions by Lousã (2013) in the case studies

\begin{tabular}{|c|c|c|c|c|}
\hline Innovation dimensions & Firm A & Firm B & Firm C & Firm D \\
\hline \multicolumn{5}{|l|}{ Resources } \\
\hline $\begin{array}{l}\text { Number of employees } \\
\text { (2017) }\end{array}$ & 18 & 133 & 58 & 20 \\
\hline $\begin{array}{l}\text { Percentage of staff involved } \\
\text { in lifelong learning/ training } \\
\text { activities } \\
\text { (variation, } \Delta, 2015-2017 \text { ) }\end{array}$ & & $\begin{array}{l}90 \% \\
(\Delta=0)\end{array}$ & $\begin{array}{c}36 \% \\
(\Delta=+22)\end{array}$ & \\
\hline $\begin{array}{l}\text { Investment in R\&D } \\
(\text { variation }(\Delta) 2015-2017)\end{array}$ & & $\Delta=+31 \%$ & & \\
\hline \multicolumn{5}{|l|}{ Processes } \\
\hline $\begin{array}{l}\text { Partnerships and } \\
\text { Cooperation - Clients } \\
\text { number and variation }(\Delta)\end{array}$ & & $\begin{array}{c}3 \\
(\Delta=+2)\end{array}$ & $\begin{array}{c}1 \\
(\Delta=0)\end{array}$ & \\
\hline $\begin{array}{l}\text { Partnerships and } \\
\text { Cooperation with higher } \\
\text { education institutions: } \\
\text { - } \quad \text { Partnership in } \\
\text { master degree } \\
\text { dissertation } \\
-\quad \text { Curricular } \\
\text { internship } \\
-\quad \text { Recruitment } \\
-\quad \text { Job fairs in several } \\
\\
\text { universities }\end{array}$ & & $\begin{array}{l}X \\
X \\
X\end{array}$ & $\begin{array}{l}X \\
X\end{array}$ & \\
\hline
\end{tabular}




\begin{tabular}{|c|c|c|c|c|}
\hline $\begin{array}{ll} & \text { Seminars/talks in } \\
\text { universities by } \\
\text { employees }\end{array}$ & & & & \\
\hline $\begin{array}{l}\text { Protection and } \\
\text { enhancement of knowledge } \\
\text { (number of patents) }\end{array}$ & & & 1 & \\
\hline $\begin{array}{l}\text { Internal activities for } \\
\text { innovation }\end{array}$ & $\begin{array}{l}\text { Based on } \\
\text { proposed } \\
\text { ideas, their } \\
\text { registration, } \\
\text { evaluation } \\
\text { and } \\
\text { implementatio } \\
\text { n }\end{array}$ & $\begin{array}{l}\text { Ideas come up } \\
\text { after } \\
\text { fortnightly } \\
\text { meetings } \\
\text { where the } \\
\text { team looks at } \\
\text { how to } \\
\text { improve the } \\
\text { work for the } \\
\text { project } \\
\text { concerned and } \\
\text { the work } \\
\text { environment } \\
\text { (not during } \\
\text { the meetings) }\end{array}$ & $\begin{array}{l}\text { Ideas come } \\
\text { from various } \\
\text { sources: } \\
\text { conversations } \\
\text { between } \\
\text { employees, } \\
\text { brainstorming } \\
\text { ' programming } \\
\text { marathons, } \\
\text { and the CEO. } \\
\text { Subsequently, } \\
\text { a proof of } \\
\text { concept, } \\
\text { implementatio } \\
\text { nand } \\
\text { production }\end{array}$ & $\begin{array}{l}\text { Idea } \\
\text { generation - } \\
\text { brainstorming } \\
\text { ' } \\
\text { Product } \\
\text { design, } \\
\text { functionality } \\
\text { and testing } \\
\text { before } \\
\text { entering the } \\
\text { market. }\end{array}$ \\
\hline
\end{tabular}

Table 3: Innovation dimensions by Lousã (2013) in the case studies(Continues)

\begin{tabular}{|c|c|c|c|c|}
\hline Innovation dimensions & Firm A & Firm B & Firm C & Firm D \\
\hline Certifications & $\begin{array}{l}\text { Not anymore, } \\
\text { used to be } \\
\text { certified by } \\
\text { NP } 44572007 \\
\text { (Research, } \\
\text { Development, } \\
\text { and } \\
\text { Innovation } \\
\text { Management) }\end{array}$ & & & \\
\hline \multicolumn{5}{|l|}{$\begin{array}{l}\text { Results / } \\
\text { Organizational } \\
\text { performance }\end{array}$} \\
\hline $\begin{array}{l}\text { Types of innovation } \\
\text { - Product } \\
\text { - Process } \\
\text { - Organizational } \\
\text { - Marketing }\end{array}$ & $\mathrm{X}$ & $\begin{array}{l}X \\
X\end{array}$ & $\begin{array}{l}X \\
X \\
X\end{array}$ & $\mathrm{X}$ \\
\hline $\begin{array}{l}\text { Variation of sales }(\Delta) 2017- \\
2015^{*}\end{array}$ & $+6 \%$ & $+73 \%$ & $+66 \%$ & $-1 \%$ \\
\hline $\begin{array}{l}\text { Productivity per employee } * \\
\text { - variation }(\Delta) \text { 2017-2015 } \\
\text { - comparison between cases }\end{array}$ & $\begin{array}{l}+6 \% \\
10 \% \\
\end{array}$ & $\begin{array}{l}-13 \% \\
-19 \% \\
\end{array}$ & $\begin{array}{l}+27 \% \\
100 \%\end{array}$ & $\begin{array}{l}+23 \% \\
19 \% \\
\end{array}$ \\
\hline Profit per employee* & & & & \\
\hline
\end{tabular}




\begin{tabular}{|c|c|c|c|c|}
\hline - variation $(\Delta)$ & $+55 \%$ & $-9 \%$ & $+26 \%$ & $-8 \%$ \\
\hline $\begin{array}{l}\text { Volume of sales of new } \\
\text { products/services or those } \\
\text { that significantly improved } \\
\text { (Number and variation, } \Delta \text { ) }\end{array}$ & & $\begin{array}{c}3 \\
(\Delta=+2)\end{array}$ & $\begin{array}{c}1 \\
(\Delta=0)\end{array}$ & \\
\hline $\begin{array}{l}\text { Employment growth* } \\
\text { - variation }(\Delta) \text { 2015-2017 } \\
\text { - comparison between cases }\end{array}$ & $\begin{array}{c}\Delta=0 \\
0 \%\end{array}$ & $\begin{array}{c}\Delta=+102 \\
100 \%\end{array}$ & $\begin{array}{c}\Delta=+22 \\
23 \%\end{array}$ & $\begin{array}{c}\Delta=-4 \\
-4 \%\end{array}$ \\
\hline
\end{tabular}

* Source SABI

Regarding resources in the innovation model, there are two small firms $(A, n=18$ and $D, n=20)$ and two medium-size firms (B, $\mathrm{n}=133$ and $\mathrm{C}, \mathrm{n}=58$ ). There is a higher percentage of employees in firm $B$ that participate in training than firm C. However, only firm B mentioned investment in research and development, in which the budget increased by $31 \%$ from 2015 to 2017.

In what comes to processes of the innovation model, Firm B increased the number of clients in the period under study $(n=3)$ and has a wider range of types of cooperation with Higher Education Institutions. Firm C holds one patent.

Findings show that there are no formal or regular procedures in neither case studies regarding the innovation activity and that it happens in an emerging and organic way. Generally speaking, in firm A, it is based on ideas, registration, evaluation and implementation. Although it is not certified any more, firm $\mathrm{C}$, during the period in which it was certified, integrated the structure and the philosophy of the Research, Development and Innovation Management norm. Firm B refers that the ideas usually come up retrospectively, i.e. after fortnightly meetings where the team looks at how to improve the work for the project concerned and the work environment. In firm C, ideas come from various sources: conversations between employees, brainstorming, programming marathons and the CEO. Subsequently, a proof of concept, implementation and production is performed. Innovation activity in firm D begins in meetings that favor a creative environment after approved ideas; there is product design, functionality and testing before entering the market. Although not formalized, Firm D meets the phases defined by Dantas and Moreira (2011), namely strategic reflection, generation of new solutions, implementation and dissemination.

None of the case studies referred to the marketing type of innovation. Firm $\mathrm{C}$ stated that it has product, process and organizational types of innovation. Firm B mentioned being innovative regarding product and organizational issues. The other firms (A and D) only refered to innovation on the product level.

Firm $B$ is the biggest firm in this study $(n=133)$ and the one that grew the most employees $(+102)$ during the three years under study. Firm $B$ is also the one with a negative variation of productivity and profit, when compared to the other case studies. The longitudinal data of this study allows to understand that these negative results are due to the firm's fast growth.

Firm $\mathrm{C}$ is the one with the highest productivity among case studies as it grew with 23 employees. It is not the one with the best profit per employee, even though it is positive $(+26 \%)$.

Firm A has the highest variation of profit per employee between 2015 and 2017 (+55\%). Firm D decreased the number of employees as well as the profit in this period, up to a negative level (-9\%). 


\section{Discussion and Conclusions}

To investigate the specificities of the relation between HRM practices and innovation/performance in IT firms, four case studies in this sector were studied.

When analyzing the HRM practices, findings show that recruitment and selection, as well as compensation and benefits, are the most used in the studied firms. This result is congruent with the war for talent that the high-tech industry is facing (Hays, 2019 and OECD, 2019). While OECD (2019) annual employment outlook report highlights the labor market's megatrends driven by the technological change, Hays' (2019) study shows that it is hard to recruit professionals due to the continuous and increasing need for the IT /high-tech sector. Hays (2019) refers to the small pool of talent and also the fact that candidates are not much available for a change. This study also showed that professionals value the salary offer and the career plan, which is consistent with the study of Schlechter, Hung \& Bussin (2014) that shows that high levels of remuneration, benefits and variable pay are necessary to attract this kind of workers. Although a high level of compensation is attractive in all industry sectors, the preposition that is specifically related to the IT industry can be formulated as follow:

Emphasis on recruitment and selection, as well as a high level of compensation (salary, benefits and non-financial pay) are characteristics of HRM practices in the IT industry, as a result of an increasing need for this kind of workers; therefore, they are not distinctive among firms in this industry.

Even though literature and the findings of this study point out that HRM practices bundles, which complement the effect of each other, have the biggest effect on innovation (e.g. Seeck and Diehl, 2016), some studies research the effect of individual practices. When considering the
IT sector, Laursen and Foss (2003) found that the HRM system that emphasized training performed better.

Contingent pay, when analyzed individually, seems to harm innovation (Seeck and Diehl, 2016). However, the effect of contingent pay had a positive effect on innovation when combined with other HRM practices that aimed at promoting exploratory learning (Shipton et al. 2006). These findings are also congruent with Li, Zhao and Liu's (2006) study of Chinese high-tech firms which concluded that: material incentives and fixed or material performance targets have a significant negative effect on innovation, while training, non-material incentives, work feedback and collaboration have a positive effect.

This study's findings seem to confirm these results. Firm $B$ was the only firm that did not have contingent pay or bonuses, or performance management or appraisal, and had the fastest growth and innovation. Also, it did not mention many training activities, compared to the other firms, yet they reported that $90 \%$ of their staff engage in training activities. Also, the other firms which have contingent pay and performance appraisal systems, because they also have training activities, the negative effects of the primer are balanced by the positive effects of the later.

Overall, the categories of HRM practices that bring together the most significant number of individual practices in the four-firm studies are compensation and benefits, and recruitment and selection. Analyzing the compensation and benefits category is one of the most commonly used HRM practice categories in firm studies. Firm $\mathrm{C}$ has the same number of individual practices as Firms $\mathrm{A}$ and $\mathrm{D}$. In the training and development category, Firm C brings together a more significant number of individual practices compared to the other firms and has a patent (utility model; called smart SMS).

This finding points to the following preposition:

$$
\begin{aligned}
& \text { it seems that the production of } \\
& \text { patents/utility models in }
\end{aligned}
$$


organisations is more related to the investment in training and development then to compensation, considering that in a "war for talent" context, Compensation and Benefits practices is generalised in the IT sector.

Literature shows a positive relationship between human resource management and innovation (De Winne and Sels, 2010; Jiménez-Jiménez and Sanz-Valle, 2008, and Shipton, West, Dawson, Birdi and Patterson, 2006), which seems to be confirmed by data in this study.

Firm $\mathrm{C}$ is the firm which, by far, uses the higher number of HRM practices and also the one with the very good innovation indicators: partnerships with higher education institutions, types of innovation, productivity, profit and employment growth. It is the firm that has more types of innovation, and also the best productivity and profit results throughout the three years under study while growing in the number of employees. At the same time, Firm D is the one that uses the least number of HRM practices, mainly focusing on the compensation and benefits practice. It is the one that acknowledges that there is no special alignment between HRM practices and innovation and performance indicators, they 'happen' in the informal way of working. Moreover, innovation and performance results are the worst among the studied firms. This data confirms the relation between HRM practices-innovation performance.

Firm B's findings bring something that seems controversial to the relation between HRM practices and innovation performance. This firm, HRM wise, refers to few HRM practices when compared to the other firms, and at the same time, has the best employment growth. It was the one that increased the number of clients, as well as the best sales increase regarding new products. Only the productivity/profit per employee has decreased, because of this rapid growth.

Regarding HRM practices, this firm is also different since it states its management philosophy, not having formally defined processes, and granting autonomy to its employees and teams to self-manage. This management style is congruent with the HRM practices included in the Job and Work Design category, such as participatory and decentralized decision making, selfmanaged work teams, extended task liability and flexible schedule. Job and Work Design practices are the ones that are the most referred to in this firm. At the same time, there are not many HRM practices, when compared to other firms, which is also congruent with the philosophy of not having formal procedures. However, since employees and teams work in a self satisfactory way, the HRM practices may occur only in an informal random way, only when they are considered necessary. This kind of practice relates to employees' motivation and satisfaction and influences employees allowing them to utilize their skills in the job (Berg, 1999).

Perdomo-Ortiz, González-Benito and Galende (2009) found that autonomy positively affects non-technological innovation. The data in this paper extend this result to the technological field of innovation. The preposition which is specifically related to the IT industry can be formulated as follows:

\begin{abstract}
HRM practices that aim at autonomy and self-management have a positive effect on innovation in the IT firms and can be at least as effective as corporate and formal HRM practices.
\end{abstract}

\section{Contributions to literature}

Few qualitative studies are investigating the HRM-innovation-performance link (Seeck and Diehl, 2016), even though the results of this study are consistent with previous studies (e.g. Jiménez-Jiménez and SanzValle, 2008, and Seeck and Diehl, 2016) so far as it emphasizes that human resources practices can support innovation and organizational performance, with the prepositions that are specific in the IT sector. This study has contributed to advances in this field of study. 
The analysis of the three years instead of a cross-sectional analysis and the use of the objective measures are interesting methodological features in the present study since most of the innovation and performance measures existing in the previous literature are perceptive. Findings using this type of measure add interesting support to prior studies.

\section{Limitations and Future Research}

One limitation to point out in this study was the difficulty of collecting relevant data from some of the firms. Considering the informality of the approach to innovation of the firms, further analysis was difficult.

The scarce literature on the specific sector and the methodological approach used allowed the authors of this paper to deduce prepositions. These prepositions should be used as clues to future research and to better understand the relationship between HRM practices and their impact regarding performance and innovation. The prepositions of this study may underpin hypotheses for further quantitative studies and in various contexts within the IT sector. It is also relevant to study further the various dimensions of innovation performance so that new researchers can pursue and increase the scope of the presented analysis. Finally, it is necessary to underline the contribution of this study to future literature and research, as there are few studies related to the HRM practicesinnovation-performance relation in the IT sector.

\section{References}

- $\quad$ Adams, R., Bessant, J., and Phelps, R. (2006), Innovation management measurement: A review`, International Journal of Management Reviews, 8(1), 21-47. doi:10.1111/j.14682370.2006.00119.x

- Amabile, T. M., Conti, R., Coon, H., Lazenby, J., and Herron, M. (1996), Assessing the work environment for creativity', Academy of Management Journal, 39(5), 11541184. doi: $10.2307 / 256995$
- Bardin, L. (2018) Análise de conteúdo, Lisboa: Edições 70.

- $\quad$ Becker, B., and Gerhart, B. (1996), 'The impact of human resource management on organizational performance: Progress and prospects',Academy of Management Journal, 39, 779-801.

- Berg, P. (1999), 'The Effects of High Performance Work Practices on Job Satisfaction in the United States Steel Industry', Relations Industrielles, 54(1), 111. doi:10.7202/051222ar

- $\quad$ Boselie, P., Paauwe, J. and Jansen, P. (2001),'Human resource management and performance: lessons from the Netherlands', International Journal of Human Resource Management, 12 (7), 1107-1125.

- Chen, C and Huang, J. (2009), 'Strategic human resource practices and innovation performance - The mediating role of knowledge management capacity',Journal of Business Research, 62, 104-114.

- Combs, J., Liu, Y., Hall, A., and Ketchen, D. (2006), 'How much do highperformance work practices matter? A meta-analysis of their effects on organizational performance', Personnel Psychology, 59, 501-528.

- Damanpour, F., and Schneider, M. (2006), 'Phases of the adoption of innovation in organizations: Effects of environment, organization and top managers', British Journal of Management, 17(3), 215-236. doi: 10.1111/j.1467-8551.2006.00498.x

- De Winne, S., \& Sels, L. (2010). Interrelationships between human capital, HRM and innovation in Belgian start-ups aiming at an innovation strategy. The International Journal of Human Resource Management, 21(11), 18631883. doi:10.1080/09585192.2010.50 5088 
- Diaz-Fernandez, M., BornayBarrachina, M. and Lopez-Cabrales, A. (2017), 'HRM practices and innovation performance: a panel-data approach', International Journal of Manpower, 38 (3), 354-372.

- Donate, M. J., Peña, I. and Pablo, J. (2016), 'HRM practices for human and social capital development: effects on innovation capabilities', The International Journal of Human Resource Management, 27 (9), 928-953.

- Galbraith, J.R. (1984), `Human Resource Policies for the Innovating Organization', In Strategic Human Resource Management, Edited by: Fobrun, C., Tichy, N.M. and Devanna, M.A. 319-341. USA: John Wiley \& Sons.

- Gomes, J., Hurmelina, P. and Olander, H. (2018), 'HR Practices, knowledge sharing and protection activities, and performance - a moderation model', International Journal of Innovation Management, 22 (1), 1-15.

- Hays (2019), Guia do Mercado Laboral 2020.

- Hong, J., Zhao, X. and Snell, R. (2018), 'Collaborative-based HRM practices and open innovation: a conceptual review', The International Journal of Human Resource Management, 1-32.

- Huselid, M. (1995), 'The impact of human resource management practices on turnover, productivity, and corporate financial performance', Academy of Management Journal, 38, 635-672.

- Jiménez-Jiménez, D. and Sanz-Valle, R. (2008), 'Could HRM support organisational innovation?',The International Journal of Human Resource Management, 19 (7), 12081221.

- $\quad$ McAfee, A., and Brynjolfsson, E. (2008), 'Investing in the It That Makes a Competitive Difference', Harvard Business Review, 86 (7/8), 98-107.
- Laursen, K., and Foss, N. J. (2014), Human resource management practices and innovation. In $M$. Dodgson, D. Gann, \& N. Phillips (Eds.), Handbook of innovation management (pp. 505-530), Oxford: Oxford University Press.

- Li, Y., Zhao, Y., \& Liu, Y. (2006), 'The relationship between HRM, technology innovation and performance in China', International Journal of Manpower, 27, 679-697.

- Lousã, E. P. (2013),Liderança empreendedora e cultura de inovação em organizações de base tecnológica e análise comparativa entre setores de atividade (Tese de doutoramento não publicada), Universidade de Coimbra, Faculdade de Psicologia e de Ciências da Educação, Portugal.

- Lousã, E.P. and Gomes, A. D. (2017), 'The influence of technology, organisational size and age on Innovation', RevistaPsicologia: Organizações e Trabalho, 17 (4), 252259.

- OECD (2005),Oslo Manual Guidelines for collecting and interpreting innovation data, Paris: OECD Publications.

- OECD (2019), OECD Employment Outlook 2019: The Future of Work, OECD Publishing, Paris, https://doi.org/10.1787/9ee001 55-en.

- Pan, Yang, Huang, Peng and Gopal (2016), 'Board Independence and Firm Performance in the IT Industry: The Moderating Role of New Entry Threats'.Robert H. Smith School Research PaperNo. RHS 2835117. Available at SSRN: https://ssrn.com/abstract $=2835117$ or http://dx.doi.org/10.2139/ssrn.28351 17

- Posthuma, R. A., Campion, M. C., Masimova, M. and Campion, M. A. 
(2013), 'A high performance work practices taxonomy: integrating the literature and directing future research', Journal of Management, 20 (10), 1-37.

- Perdomo-Ortiz, J., González-Benito, J., and Galende, J. (2009),'An analysis of the relationship between total quality management-based human resource management practices and innovation',International Journal of Human Resource Management, 20, 1191-1218.

- Rauch, A., Frese, M., andUtsch, A. (2005), 'Effects of Human capital and Long-term Human Resources Development and Utilization on Employment Growth on Small Scale Businesses: A Causal Analysis', Entrepreneurship Theory and Practice, 29 (6), 681- 698.

- Rauch, A. andHatak, I. (2016), 'A metaanalysis of different HR-enhancing practices and performance of small and medium sized firms', Journal of Business Venturing, 31, 485-504.

- Seeck, H. and Diehl, M. (2016), 'A literature review on HRM and innovation- taking stock and future directions', The International Journal of Human Resource Management, 28 (6), 913-944.

- $\quad$ Shipton, H., West, M.A., Dawson, J., Birdi, K. and Patterson, M. (2006), HRM as a predictor of innovation. Human
Resource Management Journal, 16: 327. doi:10.1111/j.1748-

8583.2006.00002.x

- Shipton, H., Fay, D., West, M., Patterson, M., andBirdi, K. (2005), 'Managing people to promote innovation', Creativity and Innovation Management, 14(2), 118-128.

- Subramony, M. (2009), 'A meta-analytic investigation of the relationship between HRM bundles and firm performance', Human Resource Management, 48 (5), 745-768.

- Thorpe, R., and Clarke, J. (2008), 'Performance in Small Firms', In Performance Management. Multidisciplinary Perspectives (Palgrave Macmillan).

- Verburg, R. M., Den Hartog, D. N., and Koopman, P. L. (2007). 'Configurations of human resource management practices: A model and test of internal fit'International Journal of Human Resource Management, 18, 184-208.

- Wolfe, R. (1994), 'Organizational innovation: Review, critique and suggested research directions'. Journal of Management Studies, 31, 405-431. doi: 10.1111/j.1467-

6486.1994.tb00624.x

- Yin, R. K. (1994) Case Study Research: Design and Methods (2nd edition),Beverly Hills, CA: Sage Publications. 
Appendix A - Detailed HRM practices in the case studies (Posthuma et al., 2013)

\begin{tabular}{|c|c|c|c|c|}
\hline $\begin{array}{l}\text { HRM categories and their individual } \\
\text { HRM practices }\end{array}$ & Firm A & Firm B & Firm C & Firm D \\
\hline & 19 & 16 & 24 & 15 \\
\hline CompensationandBenefits & 5 & 2 & 3 & 4 \\
\hline Pay for performance & $\mathrm{x}$ & & $\mathrm{x}$ & $\mathrm{x}$ \\
\hline Payment by a formal assessment & $\mathrm{x}$ & & & $\mathrm{x}$ \\
\hline $\begin{array}{l}\text { Market Compliant External Pay Equity / } \\
\text { Salary Bands }\end{array}$ & $\mathrm{x}$ & & & \\
\hline \multicolumn{5}{|l|}{ Incentive system } \\
\hline ComprehensiveBenefits & $\mathrm{x}$ & $\mathrm{x}$ & $\mathrm{x}$ & $\mathrm{x}$ \\
\hline \multicolumn{5}{|l|}{ Profit-Sharing } \\
\hline \multicolumn{5}{|l|}{ Pay for team results } \\
\hline Payment for skills/knowledge & & $\mathrm{x}$ & & \\
\hline \multicolumn{5}{|l|}{ Employeeswithshareholderparticipation } \\
\hline Performance BonusorPrize & $\mathrm{x}$ & & $\mathrm{x}$ & $\mathrm{x}$ \\
\hline \multicolumn{5}{|l|}{ Equitablepayment processes } \\
\hline \multicolumn{5}{|l|}{$\begin{array}{l}\text { Public Recognition / Non-Financial } \\
\text { Rewards }\end{array}$} \\
\hline Job andWork Design & 1 & 5 & 2 & 2 \\
\hline $\begin{array}{l}\text { Participatory and decentralized decision } \\
\text { making }\end{array}$ & & $\mathrm{x}$ & & \\
\hline Project teams or other temporary teams & & & & $\mathrm{x}$ \\
\hline \multicolumn{5}{|l|}{ FunctionAnalysis } \\
\hline \multicolumn{5}{|l|}{ FunctionRotation } \\
\hline $\begin{array}{l}\text { Self-managed work teams (quality } \\
\text { circles) }\end{array}$ & & $\mathrm{x}$ & $\mathrm{x}$ & \\
\hline FreedomandAutonomy & & $\mathrm{x}$ & & \\
\hline \multicolumn{5}{|l|}{ Job Enrichment } \\
\hline ExtendedTaskLiability & & $\mathrm{x}$ & & \\
\hline Flexibleschedule & $\mathrm{x}$ & $\mathrm{x}$ & $\mathrm{x}$ & $\mathrm{x}$ \\
\hline Training anddevelopment & 3 & 1 & 4 & 2 \\
\hline Training Investment (hours, budget) & $\mathrm{x}$ & $\mathrm{x}$ & $\mathrm{x}$ & $\mathrm{x}$ \\
\hline Using training to improve performance & & & $\mathrm{x}$ & $\mathrm{x}$ \\
\hline $\begin{array}{l}\text { Training and development of company- } \\
\text { specific skills }\end{array}$ & $\mathrm{x}$ & & $\mathrm{x}$ & \\
\hline \multicolumn{5}{|l|}{ CareerDevelopment Training } \\
\hline \multicolumn{5}{|l|}{ Training Evaluation } \\
\hline Multidisciplinary training & & & & \\
\hline
\end{tabular}




\begin{tabular}{|l|l|l|l|l|l|}
\hline Training and mentoring new employees & $\mathrm{x}$ & & $\mathrm{x}$ & \\
\hline
\end{tabular}

\section{Appendix A (Continues)}

\begin{tabular}{|c|c|c|c|c|}
\hline $\begin{array}{l}\text { HRM categories and their individual } \\
\text { HRM practices }\end{array}$ & Firm A & Firm B & Firm C & Firm D \\
\hline Recruitment and selection & 3 & 4 & 6 & 3 \\
\hline \multicolumn{5}{|l|}{ Hiring selectivity or low selection rate } \\
\hline Specific and explicit hiring criteria & & & $\bar{x}$ & \\
\hline Using Multiple Selection Tools & $\mathrm{x}$ & $\mathrm{x}$ & $\bar{x}$ & $\mathrm{x}$ \\
\hline Structured job tests or interviews & $\mathrm{x}$ & $\mathrm{x}$ & $\mathrm{x}$ & $\mathrm{x}$ \\
\hline $\begin{array}{l}\text { Personnel selection and hiring process } \\
\text { planning }\end{array}$ & & & $\mathrm{x}$ & \\
\hline $\begin{array}{l}\text { Candidate framework with company } \\
\text { strategy }\end{array}$ & & $\mathrm{x}$ & $\mathrm{x}$ & \\
\hline Innovative Recruitment Practices & $\mathrm{x}$ & $\bar{x}$ & $\mathrm{x}$ & $\mathrm{x}$ \\
\hline $\begin{array}{l}\text { Employee Relationship / Work } \\
\text { Environment }\end{array}$ & $\mathbf{0}$ & 2 & 3 & $\mathbf{0}$ \\
\hline $\begin{array}{l}\text { Job security / Emphasis on permanent } \\
\text { employment }\end{array}$ & & & $\mathrm{x}$ & \\
\hline Low hierarchical differentiation & & $\mathrm{x}$ & & \\
\hline \multicolumn{5}{|l|}{ Formal Complaint Procedures } \\
\hline \multicolumn{5}{|l|}{ Evaluation of Employee Relations Results } \\
\hline Employee Attitude and Opinion Surveys & & & $\mathrm{x}$ & \\
\hline \multicolumn{5}{|l|}{ Collaboration with Unions } \\
\hline Family social policies and events & & $\mathrm{x}$ & $\mathrm{x}$ & \\
\hline \multicolumn{5}{|l|}{$\begin{array}{l}\text { Diversity and Equal Employment } \\
\text { Opportunities }\end{array}$} \\
\hline Communication & 2 & 2 & 2 & 1 \\
\hline Formal Information Sharing & $\mathrm{x}$ & $\mathrm{x}$ & $\mathrm{x}$ & \\
\hline \multicolumn{5}{|l|}{$\begin{array}{l}\text { Program Information sharing regarding } \\
\text { company strategy, business, results } \\
\text { (performance) }\end{array}$} \\
\hline \multicolumn{5}{|l|}{ Suggestion System } \\
\hline $\begin{array}{l}\text { Frequent / regular meetings with } \\
\text { employees }\end{array}$ & $\mathrm{x}$ & $\mathrm{x}$ & $\mathrm{x}$ & $\mathrm{x}$ \\
\hline $\begin{array}{l}\text { Performance Management and } \\
\text { Appraisal }\end{array}$ & 4 & $\mathbf{0}$ & 2 & 3 \\
\hline $\begin{array}{l}\text { Assessment based on the outcome of } \\
\text { objectives/behaviors }\end{array}$ & $\mathrm{x}$ & & $\mathrm{x}$ & $\mathrm{x}$ \\
\hline Evaluation for development / potential & $\mathrm{x}$ & & & \\
\hline Frequent performance review meetings & & & $\bar{x}$ & $\mathrm{x}$ \\
\hline \multicolumn{5}{|l|}{ Employee involvement in goal setting } \\
\hline $\begin{array}{l}\text { Written evaluation plan with defined } \\
\text { objectives }\end{array}$ & $\mathrm{x}$ & & & \\
\hline
\end{tabular}

Eva Petiz LOUSÃ, Ana Cláudia RODRIGUES and Eulália Matos PINTO (2020), IBIMA Business 


\begin{tabular}{|l|l|l|l|l|}
\hline $\begin{array}{l}\text { Feedback from multiple sources and peer } \\
\text { review }\end{array}$ & $\mathrm{x}$ & & & $\mathrm{x}$ \\
\hline $\begin{array}{l}\text { Strategy based or team objective } \\
\text { assessment }\end{array}$ & & & & \\
\hline
\end{tabular}

\section{Appendix A (Continues)}

\begin{tabular}{|l|c|c|c|c|}
\hline $\begin{array}{l}\text { HRM categories and their individual HRM } \\
\text { practices }\end{array}$ & Firm A & Firm B & Firm C & Firm D \\
\hline Promotions / Progression & $\mathbf{0}$ & $\mathbf{0}$ & $\mathbf{2}$ & $\mathbf{0}$ \\
\hline Internal Promotions & & & & \\
\hline Objectively merit-based promotions & & & & \\
\hline Career Planning & & & $\mathrm{X}$ & \\
\hline Promotion Opportunities (e.g., Frequency) & & & & \\
\hline Career Plans \& Career Progression Levels & & & $\mathrm{x}$ & \\
\hline Succession Planning & & & & $\mathbf{0}$ \\
\hline Turnover, Retention and Exit Management & $\mathbf{1}$ & $\mathbf{0}$ & $\mathbf{0}$ \\
\hline
\end{tabular}

